Winter 2003

\title{
The Participation of States and Citizens in Global Governance
}

\author{
Saskia Sassen \\ University of Chicago
}

Follow this and additional works at: https://www.repository.law.indiana.edu/ijgls

Part of the International Law Commons

\section{Recommended Citation}

Sassen, Saskia (2003) "The Participation of States and Citizens in Global Governance," Indiana Journal of Global Legal Studies: Vol. 10 : Iss. 1 , Article 2.

Available at: https://www.repository.law.indiana.edu/ijgls/vol10/iss1/2

This Symposium is brought to you for free and open access by the Law School Journals at Digital Repository @ Maurer Law. It has been accepted for inclusion in Indiana Journal of Global Legal Studies by an authorized editor of Digital Repository @ Maurer Law. For more information, please contact rvaughan@indiana.edu.

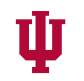

JEROME HALL LAW LIBRARY

INDIANA UNIVERSITY

Maurer School of Law
Bloomington 


\title{
The Participation of States and Citizens in Global Governance
}

\begin{abstract}
SASKIA SASSEN
The pursuit of global democratic governance cannot be confined to global institutions; national state institutions and nation-based citizens need to be part of this project. In this lecture, I want to map a variety of mechanisms and dynamics that can be seen as part of an architecture for democratic participation by state institutions and citizens in global governance. Crucial to my analysis is the notion that the global is multi-scalar: it does not take place only at the selfevident global scale, but also at the national and sub-national scales.

I identify two partly interrelated domains for exploring this topic. One domain is the ways in which the state actually participates in governing the global economy, notwithstanding expanded deregulation and privatization, and notwithstanding the growing authority of non-state actors. The question becomes one of detecting the specific type of authority/power this participation might entail for the state vis-à-vis global actors and processes. Further, if the state indeed has such authority, or could in principle have it, the question is whether that authority can be a bridge to a politics of the global for citizenswho are, after all, still largely confined to the national domain for the full exercise of their powers.

If national state participation in setting up the legal and institutional infrastructure for globalization does indeed contain a set of channels for citizens to demand participation in global politics, including the right to demand accountability from global actors, then the formal and informal capabilities of citizens to do so, as well as their disposition to do so, become crucial. This is the subject of the second domain. The organizing question is: to what extent citizenship, even though highly formalized, might actually be less finished as an

\footnotetext{
Visiting Professor at the London School of Economics. She is currently completing her forthcoming book Denationalization: Territory, Authority, and Rights in a Global Digital Age based on her five year project on governance and accountability in a global economy. Her most recent books are Guests and Aliens (1999) and her edited book Global Networks, Linked Cities (2002). The Global City is out in a new fully updated edition in 2001. Her books are translated into fourteen languages. She is a Member of the Council on Foreign Relations, a Member of the National Academy of Social Sciences Panel on Cities, and is the chair of the newly formed Information Technology, International Cooperation and Global Security Committee of the Social Science Research Council.
}

* Saskia Sassen is the Ralph Leis Professor of Sociology at the University of Chicago, and Centennial
\end{abstract}


institution than its formal representation indicates. What happens when we begin to think of this highly developed institution as something akin to an "incompletely theorized" form? Can recognition of these features help us detect the extent to which the institution might change (i.e. go partly and in very specific ways beyond its national confinements)? I am particularly interested here in the possibility that citizenship might find institutional groundings inside the nation-state that would allow citizens to participate in global politics. My concern is then not so much in the de-territorializing of the institution which lies at the heart of post-national conceptions of citizenship, including prominently the human rights regime, as it is in the denationalizing of specific features of citizenship arising out of the changes in state institutions themselves. These changes are briefly described in the first section.

It will clearly be impossible to do full justice to each of these subjects. The purpose is rather a mapping of the broader structures evident today that might be useful in situating the question of global democratic governance within a more complex and diverse set of institutional domains than is usually allowed. I should add that though the treatment of the subject is partial and brief in this lecture, it is based on a large multiyear project and hence rests on considerable evidence and research.'

1. See Saskia Sassen, Denationalization: Territory, authority, and Rights in a Global DIGITAL AGE (forthcoming 2003). 


\section{The PaRTIAL DenationalizING OF STATE WORK}

There is today a growing literature on the state and globalization. ${ }^{2} \mathrm{My}$ particular argument is that we are seeing the incipient formation of a type of authority and state practice that entails a partial denationalizing of what historically had been constructed as national. ${ }^{3}$ In this conceptualization I introduce a twist in the various analyses on the broader subject. First, my conceptualization needs to be distinguished from analyses of private authority, because these emphasize the shift out of the public domain and into the private domain. ${ }^{4}$ I seek instead to detect the presence of private agendas and authority

2. A number of scholars have addressed various dimensions of the particular issue that concerns me here, participation by the state in global processes. For some, states remain the key actors and hence not much has changed for states and the inter-state system. See generally, e.g., Stephen D. Krasner, Globalization and the State, in CONTEMPORARY DEBATES IN INTERNATIONAL RELATIONS (Edwards and Sisson eds., forthcoming 2003); Louis Pauly, Who Governs the Bankers, in PRIVATE AUTHORITY AND GLOBAL GOVERNANCE (Biersteker et al. eds., forthcoming 2003); Eric Helleiner, Sovereignty, Territoriality and the Globalization of Finance, in STATES AND SOVEREIGNTY IN THE GlOBAL ECONOMY (Smith et al. eds., 1999); PAUL HIRST \& Grahame Thompson, Globalization IN Question (1996); Challenge to the Nation-State: IMMIGRATION IN WESTERN EUROPE AND THE UNITED STATES (Christian Joppke ed., 1998). For others, even if states remain important there are today other key actors, and globalization has changed some important features of states and the interstate system. See generally, e.g., PHILIP G. CERNY, THE ChangING

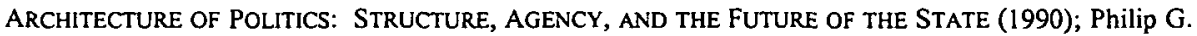
Cemy, Structuring the Political Arena: Public Goods, States and Governance in a Globalizing World, in GLOBAL POLITICAL ECONOMY: CONTEMPORARY THEORIES (Ronen Palan ed., 2000); ; PRIVATE AUTHORTY IN INTERNATIONAL AFFAIRS (Claire A. Cutler et al. eds., 1999); POLITICAL SPACE: FronTIERS OF ChANGE AND GOVERNANCE IN A GLOBALIZING WORLD (Yale H. Ferguson \& R.J.Barty Jones eds., 2002) [hereinafter POLITICAL SPACE]; Ken Dark, The Informational Reconfiguring of Global Geopolitics, in POLITICAL SPACE: FRONTIERS OF CHANGE AND GOVERNANCE IN A GLOBALIZING WORLD 61 (Yale H. Ferguson \& R.J. Barty Jones eds., 2002) [hereinafter POLITICAL SPACE]; Ronen Palan, Offshore and the Institutional Environment of Globalization, in POLITICAL SPACE, supra note 2, at 211 . For what is probably the most comprehensive mapping of the main strands in the scholarship on globalization and the state see DAVID HELD ET AL., Global TRANSFORMATIONS: POlITICS, ECONOMICS, AND CULTURE (1999), which categorizes the two major emerging strands as "hyperglobalists," who posit that national states are becoming weak and are on their way out, and transformationists, who posit that globalization has brought about significant changes in state authority and the work of states. At a time when we put increasing weight on self-reflexivity, I should perhaps clarify that Held classifies me as a transformationist, which is appropriate as far as my work on the state goes, but not quite when I look at structurations of the global that may not run through the state.

3. Even if we accept that the present era is, at a very general level, a continuation of a long history of changes that have not altered the fundamental fact of state primacy, it still leaves us with the need for detailed research about the specificities of the current changes. Along these lines of analysis, 1 argue that economic globalization is in fact a politico-economic system partly located inside national states, thereby having the effect of partly denationalizing specific, often highly specialized components of state work. See generally SASKIA SASSEN, LOSING CONTROL? SOVEREIGNTY IN AN AGE OF GLOBALIZATION, chs. 1 \& 2 (1996) [hereinafter LOSING CONTROL?]; SASSEN, supra note 1.

4. A growing literature that often overlaps with particular parts of the above cited strands in the scholarship, see supra note 2, emphasizes the relocation of national public government functions to private actors both within national and transnational domains. See, e.g., PRIVATE AUTHORITY IN INTERNATIONAL 
inside the states that are inside a domain represented as public. ${ }^{5}$ Second, it differs from an older scholarly tradition on the captured state which focused on cooptation of states by private actors, because I emphasize the privatization of norm-making capacities and the enactment of these norms in the public domain. My approach also differs from literature that emphasizes the decline and obsolescence of the state. ${ }^{6}$ It is closer to the scholarship that emphasizes state transformation, ${ }^{7}$ even though this literature tends to discard the specificity of the current phase of globalization. ${ }^{8}$

One of my efforts here, then, is to capture the blurring of some longstanding dualities in state scholarship, notably those concerning the distinctive spheres of influence of the national and the global, of state and nonstate actors, of the private and the public, respectively. ${ }^{9}$ While it may indeed be the case that the two sides of the duality are mostly separate and mutually exclusive, there are conditions or components that do not fit in this dual structure. Key among these are some components of the work of ministries of

AfFAIRS, supra note 2; Alfred C. Aman, Jr., The Globalizing State: A Future-Oriented Perspective on the Public/Private Distinction, Federalism, and Democracy, 31 VAND. J. TRANSNAT'L L. 769 (1998). For a state of the art elaboration of the rise of private authority, see generally PRIVATE AUTHORITY AND GLOBAL GOVERNANCE, supra note 2. For the emergence of cross-border governance mechanisms, see generally POLITICAL SPACE, supra note 2.

5. For a good examination of these issues as they materialize in specific institutional settings, see Aman, supra note 4. An excellent collection of essays that seeks to capture these types of dynamics can be found in TRANSNATIONAL LEGal PROCESSES (Michael Likosky ed., 2002), see especially Michael Likosky, Cultural Imperialism in the Context of Transnational Commercial Collaboration, in id.

6. Perhaps the best known, though not necessarily the most precise authors here are KENICHI OHMAE, THE END Of THE NATION-STATE: THE RISE OF REgIONAL ECONOMIES (1995) and WALTER B. WRISTON, THE TWILIGHT OF SOVEREIGNTY: HOW THE INFORMATION REVOLUTION IS TRANSFORMING OUR WORLD (1992). See also Stephen J. Kobrin, The MAI and the Clash of Globalizations, 112 FOREIGN POL'Y 97 (1998); Benjamin J. Cohen, Electronic Money: New Day or False Dawn?, 8 REV. INT'L POL. ECON. 197 (2001), available at http://www.polsci.ucsb.edu/faculty/cohen/recent/emoney.html.

7. There is today a growing literature that interprets deregulation and privatization as the incorporation by the state of its own shrinking role; in its most formalized version, this position emphasizes the state's constitutionalizing of its own diminished role. See, e.g., ROBERT W. COX, PRODUCTION, POWER, AND WORLD ORDER: SOCIAL FORCES IN THE MAKING OF HISTORY (1987); Leo Panitch, Rethinking the Role of the State, in Globalization: CRITICAL REFLECTIONS 83 (James Mittelman ed., 1996) [hereinafter CRITICAL REFLECTIONS]; Stephen Gill, The Emerging World Order and European Change, in NEW WORLD ORDER? THE SOCIALIST REgISTER 1992157 (Ralph Milliband \& Leo Panitch eds., 1992); JAMES H. MTTtelmaN, THE Globalization SYNDROME: TRANSFORMATION AND RESISTANCE (2000).

8. Perhaps the best example is Helleiner, who examines the regulatory changes brought on by the emergence of global financial systems and shows how states remain as key actors. See Helleiner, supra note 2 .

9. A good source on these dualities is THE EVOLUTION OF POLITICAL KNOWLEDGE: DEMOCRACY, AUTONOMY, AND CONFLICT IN COMPARATIVE AND INTERNATIONAL POLITICS (Edward Mansfield \& Richard Sisson eds., 2003), containing papers by major scholars in international relations addressing key issues about the state and the current features of the interstate system, with responses by critics from several disciplines. 
finance, central banks, and the increasingly specialized technical regulatory agencies, such as those concerned with finance, telecommunications, and competition policy. ${ }^{10}$ In this regard, then, my position is not comfortably subsumed under the proposition that little has changed in terms of state power, nor can it be subsumed under the proposition that the state is declining in significance.

An important methodological assumption here is that focusing on economic globalization can help us disentangle some of these issues. ${ }^{11}$ In strengthening the legitimacy of claims by foreign investors and firms, economic globalization adds to and renders visible the work of the state aimed at accommodating their rights and contracts in what remain basically national economies. These dynamics, however, can also be present when privatization and deregulation concern native firms and investors, even though in much of the world privatization and deregulation have been constituted through the entry of foreign investors and firms. A key organizing proposition, derived from my previous work on global cities, is the embeddedness of much of globalization in national economies and polities, that is to say, in a geographic terrain that has

10. See, e.g., MARK W. Zacher \& BRENT A. SUtTon, GOVERNing Global Networks: INTERNATIONAL REGIMES FOR TRANSPORTATION AND COMMUNICATIONS (1996); George A. Bermann, International Regulatory Cooperation and US Federalism, in TRANSATLANTIC REGULATORY COOPERATION: Legal Problems aNd POlitical Prospects 373-84 (Bermann et al. eds., 2000) (hereinafter TRANSATLANTIC REGULATORY COOPERATION]; Joel R. Paul, Implementing Regulatory Cooperation Through Executive Agreements and the Problem of Democratic Accountability, in TRANSATLANTIC REGULATORY COOPERATION, supra note 10, at 385-404; Robert Howse, Transatlantic Regulatory Cooperation and the Problem of Democracy, in TRANSATLANTIC REGULATORY COOPERATION, supra note 10, at 469-80.

11. Beyond issues pertaining to the global economy, the question of state participation is also at the heart of a far broader debate about globalization and the state. There is an older scholarship on world-order systems (e.g. RICHARD FALK, EXPLORATIONS AT THE EDGE OF TIME: THE PROSPECTS FOR WORLD ORDER (1992); Richard Falk, The Making of Global Citizenship, in GLOBAL VISIONS: BEYOND THE NEW WORLDORDER 3950 (Jeremy Brecher et al. eds., 1993) [hereinafter Falk, The Making of Global Citizenship]) recently invigorated by debates about cosmopolitanism. See, e.g., David Held, DEMOCRACY AND THE GLOBAL ORDER: FROM THE MODERN STATE TO COSMOPOLITAN GOVERNANCE (1995) [hereinafter DEMOCRACY AND THE GLOBAL ORDER]; HELD ET AL., supra note 2. It examines and theorizes the possibilities of transcending nationally oriented state authority and instituting world-level institutional orders. This literature often includes partial world-level orders such as the international human rights regime or certain features of international environmental treaties, and, quite prominently, discussions about the possibility of a global civil society. See generally, e.g., GLOBALIZATION AND HUMAN RIGHTS (Alison Brysk ed., 2002) (international human rights); RONNIE D. LIPSCHUTZ \& JUDITH MAYER, GLOBAL CIVIL SOCIETY AND GLOBAL ENVIRONMENTAL GOVERNANCE: THE POlitics Of NATURE fROM PlaCE to Planet (1996) (intemational environmental treaties); HELD ET AL., supra note 2; GLOBAL CIVIL SOCIETY 2002 (Glasius et al. eds., 2002) [hereinafter GLOBAL CIVIL SOCIETY 2002]. See also infra note 15. 
been encased in an elaborate set of national laws and administrative capacities. ${ }^{12}$

The embeddedness of the global requires at least a partial lifting of these national encasements and hence signals a necessary participation by the state, even when it concerns the state's own withdrawal from regulating the economy. ${ }^{13}$ The question is whether the weight of private, often foreign, interests in this specific work of the state becomes constitutive of a particular form of state authority that does not replace but works alongside older, wellestablished forms of state authority. ${ }^{14}$ My argument below will be that the mix of processes we describe as globalization is indeed producing, deep inside the national state, a very partial but significant form of authority, a hybrid that is neither fully private nor fully public, neither fully national nor fully global. ${ }^{15}$

12. For a development of some of these issues please refer to Saskia Sassen, Territory and Territoriality in the Global Economy 15 INT'L SOC. $372-93$ (2000). In this context, I find interesting parallels in a specific type of legal scholarship focused on the construction of jurisdictions and the locating of particular issues in jurisdictions that may today be less and less adequate; see, for instance the extraordinary analysis in Judith Resnik, Categorical Federalism: Jurisdiction, Gender, and the Globe, 111 YALE L.J. 619-80 (2001).

13. On the one hand, there is an enormously elaborate body of law developed in good measure over the last hundred years which secures the exclusive territorial authority of national states to an extent not seen in earlier centuries. See generally STEPHEN D. KRASNER, SOVEREIGNTY: ORGANIZED HYPOCRISY (1999); Friedrich Kratochwil, Of Systems, Boundaries, and Territoriality, 39 WORLD POL. 27 (1986); John Gerard Ruggie, Territoriality and Beyond: Problematizing Modernity in International Relations, 47 INT'L ORG. 139 (1993); HENDRICK SPRUYT, THE SOVEREIGN STATE AND ITS COMPETITORS (1994). On the other hand, we see today a considerable institutionalizing, especially in the 1990 s, of the "rights" of non-national firms, the deregulation of cross-border transactions, and the growing influence/power of some of the supranational organizations. See generally, e.g., LEGALIZATION AND WORLD POLITICS (Judith Goldstein et al. eds., 2001) [hereinafter LEGALIZATION AND WORLD POLITICS]; LLOYD GRUBER, RULING THE WORLD (2000); ROBERT O. KEOHANE \& JOSEPH S. NYE, POWER AND INTERDEPENDENCE (2001); ROBERT GILPIN \& JEAN M. GILPIN, THE Challenge of Global CAPITALISM (2000); MittelmaN, supra note 7. If securing these rights, options, and powers entailed an even partial relinquishing of components of state authority as constructed over the last century, then we can posit that this sets up the conditions for a necessary engagement by national states in the process of globalization. See generally LOSING CONTROL?, supra note 3; SASSEN, supra note 1.

14. Several scholars have focused on the nature of this engagement. See generally, e.g., Strange, supra note 2; Jan Aart Scholte, Global Capitalism and the State, 73 INT'L AfFAIRS 427 (1997); CERNY, supra note 2; Dark, supra note 2; Global CAPITALISM Versus DEMOCRACY (Leo Panitch \& Colin Leys eds., 1999) [hereinafter Global CAPITALISM VerSUS DemOCRACY]; PAUl N. DOREMUS ET AL., THE MYTH OF THE GLOBAL CORPORATION (1999); Boris Kagarlitsky, The Challenge for the Left: Reclaiming the State, in GLOBAL CAPITALISM VERSUS DEMOCRACY, supra note 14. One way of organizing the major issues is to ask whether the role of the state is simply one of reducing its authority, e.g. as suggested with terms such as deregulation and privatisation, and generally "less government," or whether it also requires the production of new types of regulations, legislative items, court decisions, in brief, the production of a whole series of new "legalities." I use this term to distinguish this production from "law" or "jurisprudence." See LosING CONTROL?, supra note 3 , ch. 1 .

15. Among the issues raised by this type of analysis are the increased autonomy and influence of the types of processes and actors described supra note 11 , as well as a variety of non-state actors. The literature on nongovermmental organizations (NGOs), including transnational ones (TNGOs), and the associated forms of 
As states participate in the implementation of cross-border regimes, whether the global economic system or the international human rights regime, they have undergone at times significant transformations because this accommodation involves a negotiation. In the case of the global economy, this negotiation entails the development inside national states-through legislative acts, court rulings, executive orders, and policy —of the mechanisms necessary for the reconstitution of certain components of national capital into "global capital," and necessary to develop and ensure new types of rights/entitlements for foreign capital $^{16}$ in what are still national territories, in principle under the exclusive authority of their states. ${ }^{17}$

These particular transformations inside the state are partial and incipient, but strategic. Such transformations can weaken or alter the organizational architecture for the implementation of international law insofar as

activism, have also generated a series of interesting insights into the changed position of states in a context of multiple globalizations. See generally, e.g., MARGARET E. KECK \& KATHRYN SIKKINK, ACTIVISTS BEYOND BORDERS: ADVOCACY NETWORKS IN INTERNATIONAL POLITICS (1998); CONTESTING GLOBAL GOVERNANCE: MULTILATERAL ECONOMIC INSTITUTIONS AND GLOBAL SOCIAL MOVEMENTS (Robert O'Brien et al. eds., 2000); CONSTRUCTING WORLD CULTURE: INTERNATIONAL NONGOVERNMENTAL ORGANIZATIONS SNCE 1875 (John Boli et al. eds., 1999). For a critical account that partly rejects the notion that these non-state actors actually represent a politics that undermines existing forms of authority, including that of the state, see Andre C. Drainville, Left Internationalism and the Politics of Resistance in the New World Order, in A NEW WORLD ORDER?: GLOBAL TRANSFORMATIONS IN THE LATE TWENTIETH CENTURY 217 (David A. Smith \& József Böröcz eds., 1995). I would also include here a variety of emergent global networks that are fighting equally emergent global agents such as trafficking gangs (e.g. Global Survival Network 1997; Coalition to Abolish Slavery and Trafficking, Annual). For a general review of these types of organizations see Saskia Sassen, The Repositioning of Citizenship: Emergent Subjects and Spaces for Politics, 46 RACE \& ETHNICITY 4 (2002). Along these lines a new set of concrete instances has come about with the September 11, 2001 attack on the World Trade Center-i.e. the use by international organized terrorism of the global financial system and the international immigration regime. For a variety of analyses, see UNDERSTANDING SEPTEMBER 11 (Craig J. Calhoun et al. eds., 2002) [hereinafter UNDERSTANDING SEPTEMBER 11]; Saskia Sassen, Global Cities and Diasporic Networks: Microsites in Global Civil Society, in GLOBAL CIVIL SOCIETY 2002, supra note 11 , at 217.

16. Seen from the perspective of firms and investors operating transnationally, the objective is to enjoy the protections traditionally exercised by the state in the national realm of the economy for national firms, notably guaranteeing property rights and contracts. How this gets done may involve a range of options. See generally, e.g., PRIVATe Authority ANd INTERNational AfFairs (Claire A. Cutler et al. eds., 1999); PRIVATE AUTHORTY AND GLOBAL GOVERNANCE, supra note 2.

17. Two very different bodies of scholarship which develop lines of analysis that can help in capturing some of these conditions are represented by the work of Rousenau, particularly his examination of the domestic "frontier" inside the national state, and by the work of Walker problematizing the distinction inside/outside in international relations theory. See JAMES N. ROSENEAU, ALONG THE DOMESTIC-FOREIGN FRONTIER: EXPLORING GOVERNANCE IN A TROUBLED WORLD (1997); R.B.J. WALKER, INSIDE/OUTSIDE: INTERNATIONAL RELATIONS AS POLITICAL THEORY (1993). An interesting variant on this subject is INTERVENTION AND TRANSNATIONALISM IN AFRICA: GLOBAL-LOCAL NETWORKS OF POWER (Thomas Callaghy et al. eds., 2001), which examines the proliferation of global non-state centered networks in the case of Africa. 
implementation depends on the institutional apparatus of national states. Further, these transformations have also created the conditions whereby some parts of national states actually gain relative power as a result of that participation in the development of a global economy. ${ }^{18}$ As particular components of national states become the institutional home for the operation of some of the dynamics that are central to globalization, they undergo change that is difficult to register or name. This is one instantiation of what I call a process of incipient denationalization - that is of specific components of national states that function as such institutional homes.

This partial, often highly specialized or at least particularized, denationalization can also take place in domains other than that of economic globalization, notably the more recent developments in the human rights regime that allow national courts to sue foreign firms and dictators ${ }^{19}$ or that grant undocumented immigrants certain rights. ${ }^{20}$ Denationalization is, thus, multivalent: it endogenizes many different types of global agendas, not only those of corporate firms and financial markets, but also human rights objectives. Here I confine myself to economic globalization.

The question for research then becomes what is actually "national" in some of the institutional components of states linked to the implementation and regulation of economic globalization. The hypothesis here would be that some components of national institutions, though formally national, are not national in the sense in which we have constructed the meaning of that term over the last hundred years. One of the roles of the state vis-à-vis today's global economy has been to negotiate the intersection of national law and foreign actorswhether firms, markets or supranational organizations. This raises a question as to whether there are particular conditions that make execution of this role in the current phase distinctive from what it may have been in earlier phases of the world economy.

We need to understand more about the nature of this engagement than is represented by concepts such as deregulation. It is becoming clear that the role of the state in the process of deregulation involves the production of new types of regulations, legislative items, court decisions ${ }^{21}$ —in brief, the production of a

18. LOSING CONTROL?, supra note 3 , chs. $1 \& 2$.

19. See, e.g., Beth Stephens, Corporate Liability: Enforcing Human Rights Through Domestic Litigation, 24 HASTINGS INT'L \& COMP. L. REV. 401 (2002).

20. I return to this issue in the second half of the lecture. See infra note 70.

21. See, e.g., Panitch, supra note 7; Phillip Cemy, Paradoxes of the Competition State: The Dynamics of Political Globalization, 32 GOV'T \& OPPOSITION 251-74 (1997). See also generally SOL PICCIOTTO, 
whole series of new "legalities."22 The state's role is also evident in the proliferation of specialized, often semi-autonomous regulatory agencies and the specialized cross-border networks they are forming, which are taking over functions once enclosed in national legal frameworks. ${ }^{23}$ The background condition here is that the state remains the ultimate guarantor of the "rights" of global capital, i.e. the protection of contracts and property rights, and, more generally, a major legitimator of claims. ${ }^{24}$ It is in this sense that the state can be seen as incorporating the work of shrinking its own role in regulating economic transactions ${ }^{25}$ and giving the global project operational effectiveness and legitimacy. ${ }^{26}$ The state here can be conceived of as representing a technical administrative capacity which at this time cannot be replicated by any other institutional arrangement. Furthermore, this is a capacity backed by military power - though exercise of this power is not an option in many countries-and by global power in the case of some states. To some extent this work of states is becoming privatized, as is signaled by the growth of international commercial

INTERNATIONAL BUSINESS TAXATION: A STUDY IN THE INTERNATIONALIZATION OF BUSNESS REGULATION (1992); SOL PICCIOTTO \& RUTH MAYNE, REGULATING INTERNATTONAL BUSINESS: BEYOND LIBERALIZATION (1999).

22. For a broad range of views see, e.g., LEgALIZATION AND WORLD POLITICs, supra note 13; Governance IN A Globalizing World (Joseph S. Nye \& John D. Donahue eds., 2000). For more particular cases of this broader issue, see PicciotTo \& MAYNE, supra note 21; Aihwa Ong, Strategic Sisterhood or Sisters in Solidarity? Questions of Communitarianism and Citizenship in Asia, 4 IND. J. GLOBAL LEGAL STUD. 107 (1996); ROSENEAU, supra note 17; BARRY EICHENGREEN \& ALBERT FISHLOW, CONTENDING WITH CAPITAL FlowS (1996); Aman, supra note 4.

23. We can see this in particular features of a variety of domains: for instance, competition policy, specific aspects of international business collaboration, in networks among members of the judiciary, and, in a very different domain, the new opening among the top leadership in a growing number of unions to organizing immigrants. See generally, e.g., EDWARD O. GRAHAM \& J.D. RICHARDSON, GLOBAL COMPETITION POLICY (1997); Brian Portnoy, Constructing Competition: The Political Foundations of Alliance Capitalism (Ph.D. dissertation, 1999) (both dealing with competition policy); JOHN DUNNING, ALLIANCE CAPITALISM AND GlobAl BUSINESS (1997); 6 IND. J. GLOBAL. L. STUD. (1998) (special issue dealing with international business collaboration); Anne-Marie Slaughter, Agencies on the Loose? Holding Government Networks Accountable, in TRANSATLANTIC REGULATORY COOPERATION, supra note 10, at $521-46$ (judicial networks); LEAH HAUS, UNIONS, IMMIGRATION, AND INTERNATIONALIZATION: NEW CHALLENGES AND CHANGING CONDITIONS IN THE UNITED STATES AND FRANCE (2002) (organizing immigrants).

24. While it is well known, it is worth remembering that this guarantee of the rights of capital is embedded in a certain type of state, a certain conception of the rights of capital, and a certain type of international legal regime: it is largely embedded in the state of the most developed and most powerful countries in the world, in westem notions of contract and property rights, and in new legal regimes aimed at furthering economic globalization-e.g. the push to get countries to support copyright law. See, e.g., Chantal Thomas, Transfer of Technology in the Contemporary International Order, 22 FORDHAM INT'L L.J. 2096, 2102-11 (1999) (discussing the handling of something as neutral in appearance as technology transfers in the emerging international legal regime for these transactions).

25. See Gill, supra note 7; Panitch, supra note 7.

26. See generally LOSING CONTROL?, supra note 3, chs. 1 \& 2; SASSEN, supra note 1. 
arbitration, ${ }^{27}$ and by key elements of the new privatized institutional order for governing the global economy. ${ }^{28}$

Legislative items, executive orders, adherence to new technical standards, and so on, will all have to be produced through the particular institutional and political structures of each participating state. Even when imposed from the outside, there is specific work that individual states need to do. ${ }^{29}$ The emergent, often imposed, consensus in the community of states to further globalization is not merely a political decision; it entails specific types of work by a large number of distinct state institutions in each of these countries. Clearly, the role of the state will vary significantly depending on the power it may have both internally and internationally. Some states, particularly the United States and the United Kingdom, are producing the design for many of these new legalities-i.e. items derived from Anglo-American commercial law and accounting standards-and are hence imposing these on other states through the interdependencies at the heart of the current phase of globalization. This creates and imposes a set of specific constraints on the other participating states. ${ }^{30}$

This dynamic contains an interesting dialectic. These types of state participation can strengthen the forces that challenge or destabilize what have historically been constructed as state powers. ${ }^{31}$ In my reading, this holds not only for weak states but also for the most powerful ones. The U.S. government, as the hegemonic power of this period, has led/forced other states to adopt these

27. See generally YVES DEZALAY \& BRYANT GaRTH, DEALING IN VIRTUE. INTERNATIONAL COMMERCIAL ARBITRATION AND THE CONSTRUCTION OF A TRANSNATIONAL LEGAL ORDER (1996); Jeswald Salacuse, Making Global Deals: Negotiating IN the INTERNational Marketplace (1991).

28. See generally PRIVATE AUTHORITY IN INTERNATIONAL AFFAIRS, supra note 2.

29. In terms of research and theorization, this is a vast uncharted terrain: it would require examining how that production takes place and gets legitimated in different countries. This signals the posibility of crossnational variations (which then would need to be established, measured, and interpreted).

30. This dominance assumes many forms and does not only affect poorer and weaker countries. France, for instance, ranks among the top providers of information services and industrial engineering services in Europe and has a strong, though not outstanding, position in financial and insurance services. However, it has found itself at an increasing disadvantage in legal and accounting services because Anglo-American law and standards dominate in international transactions. Anglo-American firms with offices in Paris service the legal needs of firms, whether French or foreign, operating out of France. See Sassen, supra note 12, at 382. Similarly, Anglo-American law is increasingly dominant in international commercial arbitration, an institution grounded in continental traditions of jurisprudence, particularly French and Swiss. See generally DEZALAY \& GARTH, supra note 27.

31. See GIOVANNI ARRIGHI, THE LONG TWENTIETH CENTURY: MONEY, POWER, AND THE ORIGINS OF OUR TIMES 239-69 (1994); see also Scholarly Controversy: Chaos and Governance, in 13 POLITICAL POWER AND SOCIAL THEORY, pt. IV (Diana E. Davis ed., 1999). 
obligations towards global capital and, in so doing, has contributed to the globalization of conditions that reduce particular forms of state authority both in the U.S. and in more and more countries around the world. This becomes evident when viewed in light of the fact that while the state continues to play a crucial, though no longer exclusive, role in the production of legality around new forms of economic activity, at least some of this production of legalities is increasingly feeding the power of new emerging structures, whether global markets for capital, the World Trade Organization, or the international human rights regime.

A crucial part of the argument is the fact of the institutional and locational embeddedness of globalization. While this is not the place to discuss this embeddedness, let me specify why it matters. ${ }^{32}$ First, it provides the empirical specification underlying my assertion that the state is engaged, which in turn feeds the proposition about the denationalizing of particular state functions and capacities. Second, it signals that the range of ways in which the state could be involved is far broader than what it is today-largely confined to furthering economic globalization.

Conceivably, state involvement could address a whole series of global issues, including the democratic deficit in the multilateral system governing globalization. ${ }^{33}$ State participation could create an enabling environment not only for global corporate capital but also for those seeking to subject the latter to greater accountability and public scrutiny. But unlike what has happened with global corporate capital, the necessary legal and administrative instruments and regimes have not been developed that would allow citizens to participate in global governance through state institutions. The trade-offs and the resources that can be mobilized are quite different in the case of citizens seeking to

32. I have developed this at greater length addressing an audience of legal scholars in Sassen, The Repositioning of Leadership, supra note 15 . See also the development of the argument focusing on private rather than state actors in SASKIA SASSEN, THE GLOBAL CITY (2nd ed., 2001).

33. There are several types of analyses that address particular forms of this question. See, e.g., HELDET AL., supra note 2; Alfred C. Aman Jr., The Globalizing State: A Future-Oriented Perspective on the Public/Private Distinction, Federalism, and Democracy, 2 IND. J. GLOBAL L. STUD. 429(1995); Aman, supra note 4 (all on how states could participate in global governance); Warren Magnusson, Politicizing the Global City, in BeING POLITICAL: GENEAlogies OF CITIZENSHIP 289 (Engin Isin ed., 2000); PolitiCAL SPACE, supra note 2 (both on how to rethink political space); A. BRYSK \& GERSHON SAFFIR, THE CITLENSHIP GAP (forthcoming 2003) (on the citizenship gap in a global world and what states could do). For a very particular angle on these issues see UNDERSTANDING SEPTEMBER 11, supra note 15, for a variety of authors seeking to understand how the World Trade Center attacks on September 11, 2001 forced a rethinking of how globalization has repositioned the U.S. state in the world and how to respond to the new types of organized international terrorism. 
globalize their capacities for governing compared to those of global capital seeking to form regimes that enable and protect it.

In the next section I examine some of these issues from the perspective of the institution of citizenship. This produces a distinct domain for global politics - one that is distinct from the notion, developed above, that state participation in the global economy should function as a bridge for a country's citizens to participate in global governance. I see, however, an emergent institutional resonance between the features of the state discussed here and the features of an evolving institution of citizenship in the next section.

\section{THE REPOSITIONING OF CITIZENSHIP}

Citizenship, the foundational institution for membership in the modern state, is being partly destabilized through current developments associated with globalization. ${ }^{34}$ Some of the major transformations occurring today under the impact of globalization may give citizenship yet another set of features as it continues to respond to the conditions within which it is embedded - a characteristic of its history. One possible materialization is that the nationalizing of the institution that took place over the last several centuries may today give way to a partial de-nationalizing. One might then hypothesize that this could produce institutional resonance with the processes of denationalization discussed in the preceding section. Such a possibility raises a number of questions for which it is too early to find answers. But, conceivably, this institutional resonance could position citizens, still largely nation-based, as participants in an emergent domain of global governance.

Though often talked about as a single concept and experienced as a unitary institution, citizenship actually describes a number of discrete but related aspects of the relationship between the individual and the polity. Current developments are bringing to light the distinctiveness of these various aspects, from formal rights to practices and psychological dimensions. ${ }^{35}$ These

34. Globalization also contributes to the destabilization of alienage, the other foundational institution for membership in the modem state. See generally Saskia Sassen, The Repositioning of Citizenship, 46 BERKELEY J. SOC. 4 (2002).

35. There is today a large body of scholarship that critiques the assumption that identity is basically tied to a national polity. It covers a broad range of positions even when the central point is the same. Compare Charles Taylor, The Politics of Recognition, in MUlticulturalism: EXAMINING THE POLITICS OF RECOGNITION 25 (Amy Gutman ed., 1994), and IRIS MARION YOUNG, JUSTICE AND THE POLITICS OF DIFFERENCE (1990) (both focusing on the fact that people often maintain stronger allegiances to and identification with particular cultural and social groups within the nation than with the nation at large), with 
developments also bring to the fore the tension between citizenship as a formal legal status and as a normative project or an aspiration. ${ }^{36}$ The formal equality that attaches to all citizens rarely embodies substantive equality in social terms. Current conditions have led to a growing emphasis on rights and aspirations that go beyond the formal legal definition of rights and obligations. ${ }^{37}$ The growing prominence of an international human rights regime has produced areas of convergence even as it has underlined the differences between citizenship rights and human rights. ${ }^{38}$

Insofar as citizenship is a status that articulates legal rights and responsibilities, the mechanisms through which this articulation is shaped and implemented can be analytically distinguished from the status itself. In the medieval cities so admired by Max Weber, it was urban residents themselves who set up the structures through which to establish and thicken the conditions of citizenship. $^{39}$ Today it is largely set up by the national state. With globalization, the associated changes in the national state, as well as the ascendance of human rights, these mechanisms may well begin to change once again. $^{40}$ Further, the actual content and shape of some of the legal rights and obligations may also change.

Marilyn Friedman, Feminism and Modern Friendship: Dislocating the Community, 99 ETHICs 275 (1989) (arguing that the notion of a national identity is based on the suppression of social and cultural differences).

36. For an example that engages the notion of global public goods or a global public commons, see Thomas W. Pogge, Cosmopolitanism and Sovereignty, 103 ETHICs 48 (1992) (identifying a sort of global sense of solidarity and identification, partly out of humanitarian convictions). Notions of the ultimate unity of human experience are part of a long tradition. Today there are also more practical considerations at work, such as global ecological interdependence, economic globalization, global media and commercial culture, all of which create structural interdependencies and senses of global responsibility. See generally, e.g., Falk, The Making of Global Citizenship, supra note 11; David B Hunter, Toward Global Citizenship in International Environmental Law, 28 WILlAMETTE L. REV. 547 (1992); DEMOCRACY AND THE GLOBAL ORDER, supra note 11 .

37. This has contributed to a reinvigoration of theoretical distinctions: communitarian and deliberative; republican and liberal; feminist, post-national and cosmopolitan notions of citizenship. See, e.g., SEYLA BENHABIB, SITUATING THE SELF: GENDER, COMMUNITY AND POSTMODERNISM IN CONTEMPORARY ETHICS (1992); THE CITIZENSHIP DEBATES: A READER (Gershon Shafir ed., 1998); Ong, supra note 22.

38. See generally GLOBALIZATION AND HUMAN RIGHTS, supra note 11; see also generally WOMEN, CITIZENSHIP AND DIFFERENCE (Nira Yuval-Davis \& Pnina Werbner eds., 1999) (a feminist perspective).

39. Important to my analysis is the fact that these urban residents were pursuing a specific project: the right to protect their property from the abuses of various powerful actors such as local lords and the church. Their project was not citizenship the way we think of it now, but in their particular material and normative practices they produced foundational elements for what eventually became the modem institution of citizenship. See Sassen, supra note 34 (illustrating the fact that current transnational practices may well be feeding the possibility of transnational notions/experiences/imaginaries of citizenship).

40. See generally DEMOCRACY, CitizenShIP AND the Global CITY (Engin F. Isin ed., 2000). For instance, a growing number of scholars concemed with identity and solidarity posit the rise of transnational identities and translocal loyalties. See, e.g., Maria de los Angeles Torres, Transnational Political and 
Many of the dynamics which built economies, polities, and societies in the nineteenth and twentieth centuries contained an articulation between the national scale and the growth of entitlements for citizens. During industrialization, class formation, class struggles, and the advantages of both employers and workers tended to scale at the national level and became identified with state-produced legislation and regulations, entitlements and obligations. The state came to be seen as a key to ensuring the well-being of significant portions of both the working class and the bourgeoisie. The development of welfare states in the twentieth century became a crucial institutional domain for granting entitlements to the poor and the disadvantaged.

The growing articulation of globalization with national economies and the associated withdrawal of the state from various spheres of citizenship entitlements raises the possibility of a corresponding dilution of loyalty to the state. ${ }^{41}$ In tum, citizens' loyalty may be less crucial to the state today than it was at a time of intense warfare and its accompanying need for loyal citizensoldiers. ${ }^{42}$ Masses of troops today can be replaced by technologically-intensive methods of warfare. Most importantly, in the highly developed world, warfare has mostly become a less significant event partly due to economic globalization,

Cultural Identities: Crossing Theoretical Borders, in BORDERLESS BORDERS (Frank Bonilla et al. eds., 1998); ARJUN APPADURA, MOdernity at LARGE: CUlTuRAL DimEnSIONS OF Globallzation (1996); Robin Cohen, Diasporas and the Nation-State: From Victims to Challengers, 72 INT'L AFF. 507, 517-18 (1996); Thomas M. Franck, Community Based on Autonomy, 36 ColUM. J. TRANSNAT'L L. 41, 42 (1997). The growth of European citizenship developing as part of the European Union (EU) integration process is seen by some as going beyond the formal status of EU citizenship. See, e.g., YASEMIN NUHOGLU SOYSAL, LIMITS OF CITIZENSHIP: MIGRANTS AND POSTNATIONAL MEMBERSHIP IN EUROPE I (1994)(discussing "the changing institution and meaning of citizenship in contemporary nation-states"); Engin F. Isin, Introduction to DEMOCRACY, CITIZENSHIP AND THE GLOBAL CITY, supra, at 1-22; Gerard Delanty, The Resurgence of the City in Europe? The Spaces of European Citizenship, in DEMOCRACY, CITIZENSHIP AND THE GLOBAL CITY, supra, at 79-92; Bryan S. Tumer, Cosmopolitan Virtue: Loyalty and the City, in DEMOCRACY, CITIZENSHIP AND THE GLOBAL CITY, supra at 129-48 (noting a growing cultural awareness of a "European identity").

41. It is important to remember that the institutionalizing of "loyalty to the state" has itself undergone major historical transformations, a fact that makes evident its historicity rather than "natural" status. Before the Industrial Revolution, this bond was seen as insoluble or at least exclusive. As Rubenstein and Adler put it, while the bond of "insoluble allegiance was defensible in times of limited individual mobility," it became difficult in the face of large scale migration which was part of the new forms of industrial development. Insoluble was gradually replaced by exclusive, hence singular but changeable allegiance as the basis of nationality. Where the doctrine of insoluble allegiance is a product of Medieval Europe, the development of exclusive allegiance reflects the political context of the second half of the nineteenth century, when state sovereignty became the organizing principle of an international system--albeit a system centered in and largely ruled by Europe. Kim Rubenstein \& Daniel Adler, International Citizenship: The Future of Nationality in a Globalized World, 7 IND. J. GLOBAL LEGAL STUD. 519, 531-33 (2000).

42. See CiTLENSHIP AND SOCIAL THEORY (Bryan S. Turner ed., 1993); Tumer, supra note 40. 
that is to say, the fact that crucial economic systems and dynamics now increasingly scale at the global level. With some exceptions, global firms and global markets do not want the rich countries to fight wars among themselves. The "international" project is radically different from what it was in the nineteenth and first half of the twentieth centuries.

The construction of political membership as a national category is for us an inherited condition. The high level of institutional formalization and sociocultural thickness of this type of membership makes it difficult to experience the historicity of this construction. It is easily naturalized. Crucial in the evolution of both citizenship and the national state has been the will of the latter to render national major conditions that might well have followed a different trajectory. Among these conditions are membership and allegiance. For most of western history, territory was subject to multiple systems of rule-the king, the local lord, the church-and so was membership. The nationalizing of territory and allegiance entailed the encasement of geographic territory into an elaborate institutional system; territory became state territoriality, and identity became nation-based citizenship.

Addressing the question of citizenship in the context of significant transformations in the condition of the national generally and the nation-state in particular entails a specific stance. It is quite possible to posit that, at the most abstract or formal level, not much has changed over the last century in the essential features of citizenship. The theoretical ground from which I address the issue is that of the historicity and the embeddedness of both categories, citizenship and the national state, rather than their purely formal features. Each of these has been constructed in elaborate and formal ways. And each has evolved historically as a tightly packaged bundle of what were in fact often rather diverse elements.

Today several major dynamics are destabilizing these particular bundlings, and bringing to the fore the fact of that bundling and its particularity. Among these dynamics are, crucially, globalization and digitization as well as a range of emergent political practices often involving hitherto silent or silenced population groups and organizations. ${ }^{43}$ Through their destabilizing effects,

43. These changes include a very broad range of dynamics and conditions, among which are the impact of global forces that challenge the authority of nation-states and in so doing not only formally reduce the power of citizens but also enable forms of "citizenship" that do not fit into the established hierarchies of formalized power between states and the interstate system. Thus I include here specific institutions such as the U.N. system and the European Union, and, in the economic realms, the new importance of the International Monetary Fund and World Bank, and new types of supranational institutions such as the World Trade 
these dynamics are producing operational and rhetorical openings for the emergence of new types of political subjects and new spatialities for politics. More broadly, the destabilizing of national state-centered hierarchies of legitimate power and allegiance has enabled a multiplication of non-formalized, or only partly formalized, political dynamics and actors. ${ }^{44}$

These developments, some advanced and others incipient, signal the need to expand the analytic terrain within which to understand the question of citizenship and citizen rights and obligations in the current era. They do not signal the overhaul of the institution. In my reading we are dealing with very partial and particular developments, though many are at the edges of the institution and are easily disregarded. Yet in my mapping of globalization today, these particular and partial transformations in state work and in citizens' work need to be recognized. The extent to which these transformations will become institutionalized and formalized is likely to vary sharply. From my perspective, it is important to capture also those changes that are not likely to become formalized, at least any time soon. This probably constitutes an important difference compared to how a legal scholar would map the issues. Nature may abhor a vacuum, but lawyers abhor informal practices and norms, no matter how thick.

Here I can address only a few of these markers of an expanded analytic terrain for understanding citizenship. Perhaps the most prominent mode of conceptualizing these kinds of developments is that they signal a deterritorializing of citizenship practices and identities, and of discourses about loyalty and allegiance. The literature on post-national citizenship captures this well. $^{45}$

Organization, all of which can determine to a large extent domestic economic performance. But these changes also include new developments of the human rights regime and the rapid growth of NGOs and TNGOs and their growing participation in cross border politics. Conceivably, these developments affect citizenship rights, even though this is typically a highly intermediated process. Some components of this process run through the changes in state institutions and policies that alter the relationship between the citizen and the state. Others run through the international human rights regime, signaling the possibility that human rights will have an expanded role in the normative regulation of politics as politics becomes more global. See SASSEN, supra note 1.

44. See Sassen, supra note 34.

45. The emergence of transnational social and political communities constituted through transborder migration is increasingly being conceptualized as the basis for new forms of citizenship identity to the extent that members maintain identification and solidarities with one another across state territorial divides. These citizenship identities arise out of networks, activities, and ideologies that span the home and the host society. See generally linda Basch et al., Nations Unbound: TRANSNational Projects, Postcolonial PREDICAMENTS, AND DETERRITORIALIZED NATION-STATES (1994); RAINER BAUBOCK, TRANSNATIONAL CITLENSHIP: MEMBERSHIP AND RIGHTS IN INTERNATIONAL MIGRATION (1994); SOYSAL, supra note 40; 
For my argument, it is important to recognize how and whether specific transformations inside the national state have directly and indirectly altered particular features of the institution of citizenship. These transformations are not predicated necessarily on deterritorialization or location of the institution outside the national state, as is key to conceptions of post-national citizenship, and hence are usefully distinguished from current notions of post-national citizenship. I refer to these as denationalized components, emergent and typically not yet formalized, in the institution of citizenship. ${ }^{46}$ By tracing what are at this time micro-transformations in the institution of citizenship on the inside of the national state (rather than outside as in post-national conceptions), I make a parallel conceptual framing to that in the first section of this lecture. ${ }^{47}$ The question then is not simply one of the deterritorializing of citizenship but also one of tracing where we see continuities and changes in the formal bundle of rights at the heart of the institution and when the changes represent a movement towards post-national and/or denationalized features of citizenship. Further, one needs to trace how informal citizenship practices engender formalizations of new types of rights.

Of particular interest to my analysis is the possibility that the formal rights of the institution also might evince change, and thereby signal that it is not necessarily a completed institution. Equal citizenship is central to the modern institution of citizenship, and the expansion of equality among citizens has shaped a good part of its evolution in the twentieth century. There is debate as to what brought about the expanded inclusions over this period, most notably the granting of the vote to women. For some, national law has been crucial in promoting measures that recognized and sought to eliminate exclusions. ${ }^{48}$ Yet, insofar as equality is based on membership, citizenship status forms the basis of an exclusive politics and identity. Politics and identity have been essential because they provide the sense of solidarity necessary for the development of modern citizenship in the nation-state.

Robert Smith, Transnational Migration, Assimilation, and Political Community, in THE CITY AND THE WORLD: NEW YORK'S GLOBAL FUTURE 110 (Margaret E. Crahan \& Alberto Vourvoulias-Bush eds., 1997).

46. But see Linda Bosniak, Citizenship Denationalized, 7 IND. J. GloBal LEGAL STUD. 447, 452 (2000) (using the term "denationalized" as interchangeable with "post-national"). Instead, I specify the theoretical and political utility of differentiating these two terms.

47. Compare the specific and partial internal reorientations to the global in national state institutions. See supra notes $15-20$ and accompanying text.

48. See, e.g., Kenneth L. Karst, Citizenship, Law, and the American Nation, 7 IND. J. GLOBAL LEGAL STUD. 595, 598 (2000). 
In a country such as the United States, the principle of equal citizenship remains unfulfilled, even after the successful struggles and legal advances of the last five decades. ${ }^{49}$ Groups defined by race, ethnicity, religion, sex, sexual orientation, and other "identities" still face various exclusions from full participation in public life. This is especially true at the level of practice even in the face of changes in formal legal status. Second, because full participation as a citizen rests on a material base, poverty excludes large sectors of the population, and the gap is widening. ${ }^{50}$ Feminist and race-critical scholarships have highlighted the failure of gender-and race-neutral conceptions, such as the legal status of citizenship, to account for the differences of individuals within communities. ${ }^{51}$ In brief, legal citizenship does not always bring full and equal membership rights. Citizenship is affected by the position of different groups within a nation-state.

But the position of these different groups has also engendered the practices and struggles that forced changes in the institution of citizenship itself. For Karst, in the United States, national law "braided the strands of citizenship"formal legal status, rights, belonging -into the principle of equal citizenship. ${ }^{52}$ This took place through a series of Supreme Court decisions and acts of Congress, beginning with the Civil Rights Act of 1964. Karst emphasizes how important these constitutional and legislative instruments are, and that we cannot take citizenship for granted or be complacent about it.

There are two aspects here that matter for my argument. First, the history of interactions between differential positionings and expanded inclusions signals the possibility that the new conditions of inequality and difference evident today, and the new types of claim-making they produce, may well bring about further transformations in the institution. Citizenship is produced partly by the practices of the excluded. Second, by expanding the formal inclusionary aspect of citizenship, the national state contributed to some of the conditions that eventually would facilitate key aspects of post-national and denationalized

49. Id. at 597.

50. This is well developed in the works of Thomas H. Marshall. E.g., ThOMAS H. MarShall, Social POLICY IN THE TWENTIETH CENTURY (1975); see also Joel Handler, Quiescence: The Scylla and Charybdis of Empowerment, in LABORING Below THE LINE: THE NEW ETHNOGRAPHY OF POVERTY, Low-WAGE WORK, AND SURVIVAL IN THE GLOBAL ECONOMY (Frank Munger ed., 2002).

51. See generally Seyla Benhabib, The Claims of Culture: EQuality aNd Diversity IN the

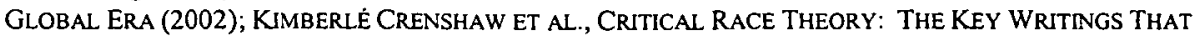
FORMED THE MOVEMENT (1995); CRITICAL RACE THEORY: THE CUTTING EDGE (Richard Delgado \& Jean Stefancic eds., 2000).

52. Karst, supra note 48 , at 597. 
citizenship. At the same time, insofar as the state itself has undergone significant transformation, notably the changes bundled under the notion of the competitive state, it may reduce the likelihood that state institutions will do the type of legislative and judiciary work that has led to expanded formal inclusions.

The consequence of these two developments may well be the absence of a linear progression in the evolution of the institution, a progression that is a key assumption in much of the literature on citizenship. ${ }^{53}$ For instance, in the case of the United States, the expanding inclusions that we have seen since the 1960s may have produced conditions which enact forms of citizenship that follow a different trajectory, e.g. minoritizing one's identity as a basis for claim-making. Additionally, the pressures of globalization on national states may mean that claim-making will increasingly be directed at other institutions as well. This is already evident in a variety of instances. One example is the decision by first-nation people to go directly to the United Nations and claim direct representation in international fora, rather than going through the particular national states within which they are subsumed. The pressures of globalization are also evident in the increasingly institutionalized framework of the international human rights regime and the emergent possibilities for bypassing unilateral state sovereignty.

As the centrality of substantive equality in citizenship has grown in importance and become a more visible issue, and as the importance of national law to giving presence/voice to silenced minorities has grown, the tension between the legal status and the normative project of citizenship has also grown. For many, citizenship is becoming a normative project whereby social membership becomes increasingly comprehensive and open-ended. ${ }^{54}$ Globalization and human rights are further enabling this tension and contributing the elements of a new discourse on rights. Though in very different ways, both globalization and the human rights regime have rendered existing political hierarchies of legitimate power and allegiance more relative over the last decade. ${ }^{55}$ All of this raises a fundamental question about what the

53. See, e.g., THOMAS H. MARSHALl \& TOM BOTTOMORE, CITIZENSHIP AND SOCIAL CLASS (1992).

54. See generally Globalization AND HuMAN RIGHTS, supra note 11. See also DAVID JACOBSON, RIGHTS ACROSS BORDERS: IMMIGRATION AND THE DECLINE OF CITIZENSHIP $38-41$ (1996); Bosniak, supra note 46 (providing a good review); Lynn A. Staeheli, Globalization and the Scales of Citizenship, 19 GEOGRAPHY RES. F. 60-77 (1999) (providing an analytic perspective). See also generally THE CITIZENSHIP DEBATES, supra note 37.

55. This is quite evident in how nationality was conceived. The aggressive nationalism and territorial competition between states in the eighteenth, nineteenth and well into the twentieth centuries made the 
analytic terrain is within which to place the question of rights, authority and obligations. ${ }^{56}$ These developments position citizens to participate in globalizing political domains through the partial reshaping of their political subjectivity.

\section{CONCLUSION}

The trends that have come together towards the end of the twentieth century are contributing to the destabilization of the meaning of citizenship as it was forged in the nineteenth and much of the twentieth centuries. Economic policies and technical developments we associate with globalization have strengthened the importance of cross-border dynamics and systems. The growing emphasis is on notions of the "competitive state" and the associated dismantling of social rights.

Emphasis on markets has brought into question the foundations of the welfare state. Marshall saw, and many others continue to see, the welfare state as an important ingredient of social citizenship. ${ }^{57}$ For many critics, the reliance on markets to solve political and social problems is a savage attack on the principles of citizenship; for others, the collapse of socialist states is a triumph of liberalism and individual rights. For instance, Saunders posits that citizenship inscribed in the institutions of the welfare state is a buffer against the vagaries of the market and the inequalities of the class system. ${ }^{58}$ Citizenship has typically been based on an individual's obligation to contribute taxes to a state system of provision. This was a key ingredient of the postwar Keynesian reconstruction based on assumptions about full employment and the

concept of dual nationality generally undesirable, incompatible with individual loyalties and destabilizing of the international order. Dual nationality was incompatible with the absolute authority of the state over its territory and its nationals. See generally IMMIGRATION AND THE POLITICS OF CITIZENSHIP IN EUROPE AND NORTH AMERICA (William Rogers Brubaker ed, 1989). Indeed, we see the development of a series of mechanisms aimed at preventing or counteracting the occurrence of de facto dual nationality, such as the redrawing of borders after wars or the imposition of a new nation-state on an underlying older one. For one of the most comprehensive examinations backed by archical research, see generally MICHAEL ROBERT MARRUS, THE UNWANTED: EUROPEAN REFUGEES IN THE TWENTIETH CENTURY (1985).

56. See generally LOSING CONTROL?, supra note 3, ch. 3.

57. See generally, e.g., LABORING BELOW THE LINE, supra note 50 (from the perspective of the social sciences); YOUTH AND WORK IN THE POSTINDUSTRIAL CITY OF NORTH AMERICA AND EUROPE (Laurence Roulleau-Berger ed., 2002) [hereinafter YOUTH AND WORK IN THE POSTINDUSTRAL CITY]; see generally Handler, supra note 50 (providing a legal scholar's perspective).

58. Peter Saunders, Citizenship in a Liberal Society, in CiTIZENSHIP AND SOCIAL THEORY, supra note 42, at 57. For an instance of extreme disentitlement in the current period, see Laura Ho et al., (Dis)Assembling Rights of Women Workers Along the Global Assembly Line: Human Rights and the Garment Industry, 31 HARV. C.R.-C.L. L. REV. 383 (1996). 
preeminence of the nuclear household and exclusive heterosexual relations. These were the assumptions of the dominant model of Marshallian citizenship. They have been severely diluted under the impact of globalization and the ascendance of the market as the preferred mechanism for addressing these social issues. ${ }^{59}$

The nature of citizenship has also been challenged by a proliferation of old issues that have gained new attention. Among the latter are the question of state membership of aboriginal communities, stateless people, and refugees. ${ }^{60}$ All of these have important implications for human rights in relation to citizenship. These social changes in the role of the nation-state, the impact of globalization on states, and the relationship between dominant and subordinate groups also have major implications for questions of identity. "Is citizenship a useful concept for exploring the problems of belonging, identity and personality in the modern world?"61 Important here is Ong's finding that in cross-border processes, individuals actually accumulate assemblages of partial rights, a form she calls flexible citizenship. ${ }^{62}$

Can such a radical change in the conditions for citizenship leave the institution itself unchanged? This question takes on added meaning when we consider the cultural and historical specificity of concepts of civil society and citizenship in Western social and political theory. ${ }^{63}$ Insofar as the new conditions evident today alter the meaning and content of civil society, they may well thereby alter citizenship.

From the perspective of nation-based citizenship theory, some of these transformations might be interpreted as a decline or devaluation of citizenship or, more favorably, as a displacement of citizenship in the face of other forms

59. Today, the growing weight given to notions of the "competitiveness" of states puts pressure on states to cut down on these entitlements. This in tum weakens the reciprocal relationship between the poor and the state. Finally, the growth of unemployment and the fact that many of the young are developing weak ties to the labor market, once thought of as a crucial mechanism for the socialization of young adults, will further weaken the loyalty and sense of reciprocity between these future adults and the state. See, e.g., YOUTH AND WORK IN THE POSTINDUSTRIAL CITY, supra note 57; LABORING BELOW THE LINE, supra note 50. For an examination of growing socio-economic inequality resulting from global integration, see Kerry Rittich, Transformed Pursuits: The Question for Equality in Globalized Markets, 13 HARV. HUM. RTS. J. 231 (2000).

60. See, e.g., KAREN KNOP, DIVERSITY AND SELF-DETERMNATION IN INTERNATIONAL LAW (2002); see also SASKIA SASSEN, The State and the Foreigner, in GUESTS AND ALIENS (1999).

61. See TURNER, supra note 42 , at ix.

62. See generally AiHWa Ong, FleXible Citizenship: The Cultural Logics Of TRanSNationality (1999).

63. See generally TURNER, supra note 42 . 
of collective organization and affiliation, as yet unnamed. ${ }^{64}$ Insofar as citizenship is theorized as necessarily national, ${ }^{65}$ by definition these new developments cannot be captured in the language of citizenship. ${ }^{66}$ An alternative interpretation would be to suspend the national, as in post-national, conceptions and to posit that the issue of where citizenship is enacted is one to be determined in light of developing social practice. ${ }^{67}$

In my view, there is a third possibility, beyond these two. It is that citizenship, even if situated in institutional settings that are "national," is a possibly changed institution if the meaning of the nation itself has changed. For me, one empirical question, then, is whether the change brought about by globalization in particular features of the territorial and institutional

64. See generally Bosniak, supra note 46 (one of the best elaborations of some of these issues); see also generally Rubenstein \& Adler, supra note 41. One issue that captures some of these transformations is the changing status of dual nationality both in legal and in more general ideological terms. There were no international accords on dual nationality for most of the history of the modem state. The negative perception of dual nationality continued into the first half of the twentieth century and well into the 1960 s. The main effort by the international system was to root out the causes of dual nationality by means of multilateral codification of the law on the subject. See generally Peter J. Spiro, Dual Nationality and the Meaning of Citizenship, 46 EMORY L.J. 1411 (1997). It was not until the 1990s that we see a proliferation of such accords. Today, more people than ever before hold dual nationality. For Spiro, this possibility of multiple allegiances indicates that national citizenship might be less important than it once was. Id. at 1414; see also SOYSAL, supra note 40; YASEMIN NuHOGlu SOYSAL, ChaNGING PaRAMETERS OF CiTIZENSHIP AND CLAIMS-MAKING: ORGANIZED ISLAM IN EUROPEAN PUBLIC SPHERES (EUI Working Papers, EUF No. 96/4, 1996); Miriam Feldblum, Reconfiguring Citizenship in Western Europe, in CHALLENGE TO THE NATIONSTATE: IMMIGRATION IN WESTERN EUROPE AND THE UNITED STATES, supra note 2, at 231 (interpreting the increase in dual nationality in terms of post-national citizenship rather than a mere devaluing of national allegiance, but I would argue that it is a partial de-nationalizing of citizenship).

65. See generally GerTRUde HiMMElfarb, ONE NATION, Two CULTURES: A SEARCHING EXAMINATION OF AMERICAN SOCIETY IN THE AFTERMATH OF OUR CULTURAL REVOLUTION (2001).

66. Thus for Karst, "[I]n the United States today, citizenship is inextricable from a complex legal framework that includes a widely accepted body of substantive law, strong law-making institutions, and lawenforcing institutions capable of performing their tasks." See Karst, supra note 48, at 600 . Not recognizing the centrality of the legal issues is, for Karst, a big mistake. Post-national citizenship lacks an institutional framework that can protect the substantive values of citizenship. Karst does acknowledge the possibility of rabid nationalism and the exclusion of aliens when legal status is made central. Id.

67. See, e.g., SOYSAL, supra note 40 , at 136-62; JACOBSON, supra note 54 , at $73-74$. There is a growing body of literature that is expanding the content of citizenship. For instance, some scholars focus on the affective connections that people establish and maintain with one another in the context of a growing transnational civil society. See generally GLOBAL CIVIL SOCIETY YEARBOOK 2002 (Helmut Anheier et al. eds., 2002) [hereinafter GLOBAL CIVIL SOCIETY YEARBOOK]; Jean Cohen, Interpreting the Notion of Global Civil Society, in I TOWARD GLOBAL CIVIL SOCIETY: INTERNATIONAL POLITICAL CURRENTS 35-40 (Michael Walzer ed., 1995); LIPSCHUTZ \& MAYER, supra note 11. Citizenship here resides in identities and commitments that arise out of crossborder affiliations, especially those associated with oppositional politics. See, e.g., Falk, The Making of Global Citizenship, supra note 11, at 39-50; see also Hunter, supra note 36, at 559-60 (for a legal elaboration). Citizenship might include, however, the corporate professional circuits that are instances of partly deterritorialized global cultures. See SASKIA SASSEN, CITIES IN A WORLD ECONOMY $111-12(2000)$. 
organization of state authority is also transforming the institution of citizenship, and, importantly, whether this transformation is occurring even when citizenship remains centered in the national state, i.e. barring post-national versions of citizenship. ${ }^{68} \mathrm{~A}$ further empirical question would be where these impacts are evident: in the formal rights of citizenship, in citizens' practices, or in the psychological dimensions of the institution.

The national remains a referent in my work-though perhaps in a different manner than in the work of a scholar such as Jacobson, whom I read as more engaged with identifying non-national locations for citizenship. But, clearly, it is a referent of a specific sort: it is, after all, the changes in state work and state authority that become the key theoretical feature through which it enters my specification/hypothesis of changes in the institution of citizenship. Whether some of these changes devalue nation-based citizenship, as Jacobson would argue, is not immediately evident to me at this point. This is partly because I read the institution of citizenship as having undergone many transformations in its history precisely because it is to variable extents embedded in the specifics of each of its eras. ${ }^{69}$ Significant here is also the fact that it was through national law that many expanded inclusions were instituted, inclusions which then in turn can destabilize older notions of citizenship. ${ }^{70}$

The pluralized meaning of citizenship, partly produced by the formal expansions of the legal status of citizenship, is today contributing to the explosion of the boundaries of that legal status, e.g. the increasing number of states that now grant dual nationality, EU citizenship, and the strengthening of

68. Bosniak grasps some of this when she asserts that for some scholars, like Jacobson and me, there is a devaluing of citizenship but that this citizenship still has the nation-state as its referent and in that regard is not a postnational interpretation. See Bosniak, supra note 46 , at 449-50.

69. In this regard, I have emphasized as significant the introduction in the new constitutions of South Africa, Brazil, Argentina and the Central European countries of a provision that qualifies what had been an unqualified right (if democratically elected) of the sovereign to be the exclusive representative of its people in intemational fora. See LOSING CONTROL?, supra note 3, at 131.

70. One such instance of destabilizing older notions of citizenship comes indirectly through changes in the institution of alienage. In Karst's interpretation of U.S. law, "aliens are constitutionally entitled to most of the guarantees of equal citizenship, and the Supreme Court has accepted this idea to a modest degree." See Karst, supra note 48, at 599 (showing cases to support this premise) (emphasis added). Karst also notes that the Supreme Court has not carried this development nearly as far as it could have (and he might wish), thereby signaling that the potential for transforming the institution may well be higher than the actual disposition to change it. Id. A significantly transformed institution of alienage would have some impact on changing at least some features of the meaning of citizenship. For a very different type of examination, see PETER H. SCHUCK \& ROGERS M. SMITH, CITIZENSHIP WITHOUT CONSENT: ILLEGAL ALIENS IN THE AMERICAN POLITY (1985). For an extraordinary account of how the U.S. polity and legal system have constructed the subject of the immigrant, particularly the "Asian-American," see DAVID PALUMBO-LIU, ASIAN-AMERICAN: HISTORICAL CROSSINGS OF A RACIAL FRONTIER (1999). 
human rights. All of these have been interpreted as loosening the "national grip" on citizens' rights. I would add two other elements that show that this loosening grip is also related to changes internal to the national state. ${ }^{71}$

First-and most importantly in my reading-is the strengthening, including the constitutionalizing, of rights that allow citizens to make claims against their states and allow them to invoke a measure of autonomy in the formal political arena that can be read as lengthening the distance between the formal apparatus of the state and the institution of citizenship. The implications, both political and theoretical, of this dimension are complex and in the making: we cannot tell what the practices and rhetoric will be that might be invented and deployed.

Second, I add to this the granting by national states of a whole range of "rights" to foreign actors, largely and especially economic actors-foreign firms, foreign investors, international markets, and foreign business people. ${ }^{72}$ Admittedly, this is not a common way of framing the issue. It comes out of my particular perspective of the impact of globalization and denationalization on the national state, including the impact on the relation between the state and its own citizens, and the state and foreign actors. I see this as a significant, though not much recognized, development in the history of claim-making. For me, the question of how citizens should handle these new concentrations of power and "legitimacy" that attach to global firms and markets is a key to the future of democracy. Detecting the extent to which the global is embedded and filtered through the national (e.g. the concept of the global city, and the issues discussed in the first section here) is one way of understanding whether a possibility lies therein for citizens, still largely confined to national institutions, to demand accountability of global economic actors through national institutional channels, rather than having to wait for a "global" state.

71. This interpretation also affects my reading of a literature that centers on location as a criterion for specifying citizenship. See, e.g., Bosniak, supra note 46, at 448-54. This criterion is rendered problematic insofar as I argue that some components of the "non-national" are embedded in the national and hence we would need to decode what is national about the national. The question of the territorial base triggers a similar problem. Id. In my reading, the meaning of the territorial has changed. See also LOSING CONTROL?, supra note 3. An added element is the emergence of digital space as significant for a whole variety of activities, from economics to citizenship practices. See, e.g., GLOBAL CIVIL SOCIETY YEARBOOK, supra note 67.

72. See LOSNG CONTROL?, supra note 3 , at 131 . 